\title{
OPTIMIZING THE SEA FOR EXTENDING MARINDA AIRPORT RUNWAY IN RAJA AMPAT
}

\author{
Bagas Dwisetiawan ${ }^{1}$, Lingga Kresna Bayu², Aditya Wardana ${ }^{3}$ \\ 1. STMT Trisakti, 2. STMT Trisakti, 3. STMT Trisakti \\ $\checkmark$ corresponding author: Setiawandwibagas@gmail.com
}

\begin{abstract}
Raja Ampat Islands is an archipelago located in Raja Ampat district in West Papua province. With the vast territory of the waters of Raja Ampat, it is possible to build airports on the waters of the Raja Ampat islands such as Kansai Airport in Japan or Ibrahim Nasir International Airport in Maldives. This study aims to determine the condition of the sea in Raja Ampat, the condition of the waves and also the location of the sea in Raja Ampat is good for the extension of the runway in order to expand the airport Marinda to support the access of foreign tourists and domestic who come to Raja Ampat which has increased in recent years. There are selections of extension to the sea due to conditions around the Marinda airport with mountainous textures.

Keywords: Raja Ampat; SingarajaMefloport; MarindaAirport; Sea; Megafloat.
\end{abstract}

\section{Introduction}

Currently, Raja Ampat has Marinda airport in Waisai newly inaugurated on May 9, 2012. However, the airport has runway with a length of 1200 meters with a width of 30 meters only. Marinda Airport has 1 apron with an area of 80 meters by 60 meters and a terminal with an area of 120 meters. Since its inception, there are only two airlines operating at Marinda airport, they are Susi Air and Wings Air. Susi Air serves only one flight a week with the Cessna Grand Caravan. While the new Wings Air operates in January 2017 serves one daily flights with ATR 72-600 aircraft. Moreover, starting on 21 October 2017 Sriwijaya Air Group, Sriwijaya Air and NAM Air will open new aviation routes to Raja Ampat from major cities such as Jakarta, Surabaya, Yogyakarta, Semarang and Makassar ("Dapat Lampu Hijau Kemenhub, Bandara Raja Ampat Siap Go International,” 2017). Uspin (2017), explained that Marinda airport is currently in the process of extending 200 meters runway to ensure the safety of ATR type aircraft (Laadala, 2017).

Data shows that the number of tourists who come to Raja Ampat is increasing, consequently, the improvement of the transport sectors, 
especially air transport must be done. Building 1880 meters or more runway extension in order to accommodate Boeing aircraft can be a solution (ICAO, 1999). Research on the journey of marine optimization for airport expansion has been done by I Nengah Adi Mahendra and friends (2015) under the title "SINGARAJA MEFLOPORT: AIRPORT WITH CONCEPT MEGAFLOAT AS NORTH BALI DEVELOPMENT DEVELOPMENT SOLUTIONS "This study discusses the idea of building an airport to make the distribution of development in the area of North Bali with the concept of" Singaraja Mefloport "as a solid solution of Ngurah Rai airport which is predicted in 2020. (Nengah Adi Mahendra, Ngurah Alit Putra Wiryawan, Gusti Ngurah Bayu Sucitra, \& Parie Perdana, 2015).

Other research has also been done by CHIAKI SATO and KEN-ICHI INOUE in the title of "RESULTS OF 6 YEARS RESEARCH PROJECT OF MEGA-FLOAT" in 2003. This research discusses the project "Mega float". The Mega float project is an airport development project over the sea. The project was conducted with various researches: research on plane landing and taking off, airport facilities, aircraft connection with fish at sea and some other research.(Sato \& Inoue, 2003)

The concept of this runway extension should be offset by the procurement of other airport facilities to support flight satisfaction and safety. The procurement of facilities at the airport should be balanced with airport services so that the concept of runway extension can increase the number of tourists coming to Raja Ampat, this can certainly increase the income of the country where it is known that Indonesia is passed by many international flight routes. (Martono \& Marina, n.d.)

\section{Method}

This study correlates the condition of a variable to other variables in order to create an opportunity that is intended in this research. This research is aimed to study the structure of the sea around the Raja Ampat archipelago in the form of depth, wave conditions and the spread of coral reef conservation area in order to extend the runway of Marinda airport to be 
accessed by large aircraft such as Boeing. SWOT method is used to identify the relation between one variable with other variables.

\section{Results and Discussion}

A. The condition of the sea in Raja Ampat

Raja Ampat Regency has 4 main islands namely Waigeo Island, Misool Island, Salawati Island and Batanta Island. While Marinda airport is located on Waigeo Island. According to BMKG data on the conditions of the waves, weather and rainfall in the islands of Raja Ampat, the highest wave is a week of 1.5 meters. And recorded maximum height can reach 2 times the wave height in the data. (Yamin \& Papua, 2017)

Table 1

\begin{tabular}{|c|c|c|c|c|c|c|c|}
\hline \multirow{3}{*}{ Kode } & \multirow{3}{*}{ Wilayah Perairan } & \multicolumn{3}{|c|}{10 Nov 2017 - 11 Nov 2017} & \multicolumn{3}{|c|}{11 Nov 2017 - 12 Nov 2017} \\
\hline & & \multicolumn{2}{|l|}{ Angin } & \multirow{2}{*}{$\begin{array}{l}\text { Gelombang } \\
(\mathrm{m})\end{array}$} & \multicolumn{2}{|l|}{ Angin } & \multirow{2}{*}{$\underset{(\mathrm{m})}{\text { Gelombang }}$} \\
\hline & & Arah & Kec (knot) & & Arah & Kec (knot) & \\
\hline Q.01 & Samudera Pasifik utara Biak & Barat Laut - Timur & $3-8$ & $0.75-1.25$ & Utara - Tenggara & $3-10$ & $0.75-1.25$ \\
\hline Q.02 & Perairan Biak & Utara - Tenggara & $3-8$ & $0.25-1.25$ & Utara - Tenggara & $3-10$ & $0.25-1.25$ \\
\hline Q.03 & Teluk Cendrawasih & Barat Daya - Utara & $3-8$ & $0.25-0.75$ & Utara - Tenggara & $3-10$ & $0.25-0.75$ \\
\hline Q.04 & Samudera Pasifik utara Jayapura & Utara - Tenggara & $3-10$ & $0.75-1.25$ & Utara - Tenggara & $3-10$ & $0.75-1.25$ \\
\hline Q.05 & Perairan Jayapura - Sarmi & Utara - Tenggara & $3-10$ & $0.25-1.25$ & Utara - Tenggara & $3-10$ & $0.25-1.25$ \\
\hline
\end{tabular}

Source:

http://maritim.bmkg.go.id/stasiun_maritim/wilayah_perairan?stasiun=kTfYK_PzIPxhrDcD ook iqhm20Cw_2Z5qpinXVT57P0\&id_perairan $=p 6 y$ Kc 3cdtgw $5 b Q Q 151 \mathrm{vdNv} 43$ emgmXIcJ VC5DGLdnG6U

Besides the wave problem, some of the waters around Raja Ampat Island become coral reef conservation area according to the ministerial decree and the decision of regent of Raja Ampat. Coral reef conservation areas in Raja Ampat include Dampier Strait KKPD, Ayau Asia KKPD, SAP Waigeo west, KKPD Mayalibit Bay, Misool KKPD, KFPD Kofiau, SAP Raja Ampat.The coral reef conservation areas closest to Marinda airport are the Mayalibit Bay KKPD and the Dampier Strait KKPD. KKPD Dampier Strait itself is located in the southern part of Marinda Airport whose seas include the sub zone of food security and tourism. ("Profil KKP," 2016) 
B. Tourist data in Raja Ampat

\section{Graph 1}

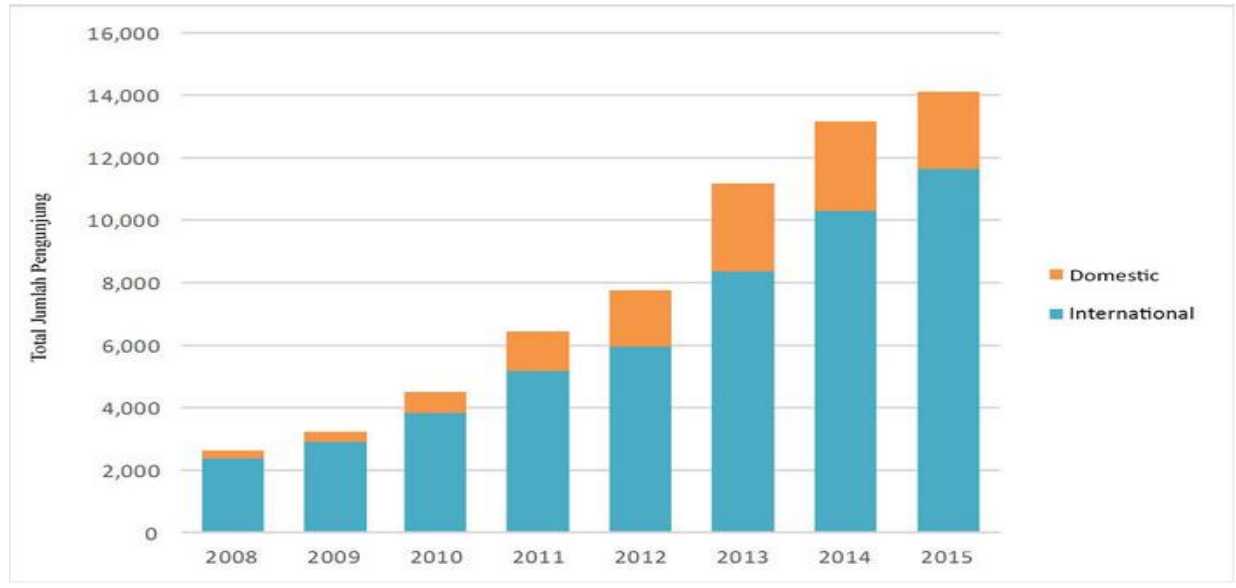

Source : http://www.kkpr4.net/index.php? page = page $\& i d=34$

Of the total data of domestic and foreign tourists who visit Raja Ampat every year is always increasing. Data shows that the number of tourists visiting Raja Ampat has increased sharply in 2008-2016. Starting from 4000 tourists coming in 2008, it then continued to reached the number of 17,000 tourists visiting Raja Ampat in 2016 ("Data Wisatawan ke Raja Ampat," 2017). From the total data of tourists listed above, it requires means of transportation that can make tourists feel comfortable, effective, and efficient.

In the year 2016 recorded data of tourists who visit Raja Ampat as shown on the graph above. In January there were 1249 foreign tourists and 207 domestic tourists. In February there are 1680 foreign visitors and 181 domestic visitors. In March there were 1688 foreign and 326 domestic visitors. In April there were 1136 foreign and 276 domestic tourists. In May there were 599 foreign and 281 domestic tourists. In June there were 345 foreign and 131 domestic tourists. In July there were 353 foreign and 222 domestic tourists. In August there are 601 overseas and 267 domestic tourists. In September, there are 887 foreign and 153 domestic tourists. In October 1738 abroad and 264 domestic tourists visited the islands. In November, there are 1790 foreign countries and 380 domestic tourists. And 
by the end of the year a number of 2149 domestic and 259 domestic tourists were recorded. The year 2016 is the peak of tourists coming to Raja Ampat in the last 10 years. With a total of 14,215 foreign tourists and 3457 domestic tourists.(“Data Wisatawan ke Raja Ampat,” 2017)

Based on the data, the numbers of foreign tourists are more than domestic tourists. This is certainly good for Raja Ampat as this means Raja Ampat is very liked by foreign tourists. However, this will be a boomerang for the government if the increase in the number of tourists who come is not balanced with the development of facilities and infrastructure. If adequate facilities and infrastructure concerns the runway capacity so that Wide Body type aircraft can access Raja Ampat territory then more demand to fly to Raja Ampat area will certainly benefit the airlines, airport or government business. (Marty, 2016) If the facilities and infrastructure and the easy accommodation is increased it will increase the number of tourists who come because the increase of facilities and infrastructure and accommodation is directly proportional to the level of satisfaction tourists. (Simarmata \& Keke, 2017)

\section{Airport Concept}

Mega float concept, popularly known as floating airport is a VLFS system (Very Large Floating System) which was first discussed for TransAtlantic Flight. For modern Mega float model, the first airport in Indonesia to implement this concept is Ahmad Yani airport in Semarang which started on June 17, 2014. The construction of this airport has 4 development packages. Ahmad Yani airport development project is projected to accommodate up to 7 million passengers.(Pura1, 2017)

The mega float concept was also designed in Japan in 1995 with a huge fund of about 9.9 billion yen for the three years. This mega float project has 2 phases. The first phase is "Research and Development of an Ultra Large Floating Structure" and the second phase is Phase II research was undertaken by the Airport Utilization Survey Investigating Meeting. The target of this project is the construction of an airport model with a 
length of about $1000 \mathrm{~m}$ and a width of $60 \mathrm{~m}$, and $3 \mathrm{~m}$ depth and draft about $1 \mathrm{~m}$. The project takes up a total of about 8.4 ha with a runway size of $900 \mathrm{~m}$ x 25m.(Sato \& Inoue, 2003).

Figure.1

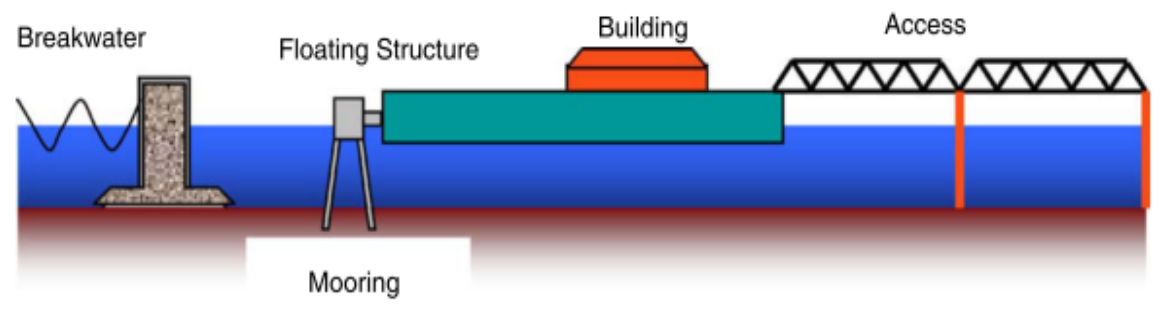

Source : (Suzuki, 2005)

Another mega float concept is also being initiated in Bali. It is in the framework of equitable development in the area of North Bali and also as a form to anticipate the density of passengers at Ngurah Rai Airport in 2020. So I Nengah Adi Mahendra and friends (2015) with the title "SINGARAJA MEFLOPORT: AIRPORT WITH MEGAFLOAT CONCEPTS AS A NORTH BALI BUILDING DEVICE SOLUTION". This research offers a solution in the form of airport development in North Bali with the concept of mega float named "Singaraja Mefloport". The Singaraja Mefloport project consists of four components: (1) broad floating aerial structure, (2) reinforcing foundation, (3) accessing bridge from ground to floating area, and (4) breakwater. With this break water component, the airport structure with the Singaraja Mefloport system does not shake when hit by the waves. And it is built with floating structure as the terminal and runway plane. Supported by a reinforcing foundation that makes the foundation of the airport remains in position when exposed to the waves.(Nengah Adi Mahendra et al., 2015).

The runway extension in the mega float concept also does not rule out Airport Master Planning. Because in the design of airport development is very complete and refers to the Airport Master Planning which includes facility requirements, airport layout plan, basic design (layout plan and 
facility design), detailed design (detailed design drawing and spesification), and air traffic forecast (passenger, air cargo, aircraft movement, peak hour forecast). (Rafi \& Rifni, n.d.)

In addition to the problems of facilities and infrastructure, one of the most important things in the aviation world is safety. Although the extension of this runway is conceptualized to the southern seas of the Marinda airport, but within the Aerodrome Safety For Manouvering Area there is a limitation of the area regarding the height of a building, mountains or other objects around the airport. (P. Ricardianto \& Rifni, n.d.) Waigeo Island is a mountainous area, so it is also involved in the concept of this runway extension. One way to solve this problem is with the construction of the Air Traffic Controller tower that complies with the regulation of its height. (R. P. Ricardianto \& An, 2015) This concept is intended to make Marinda airport a support airport in the field of tourism that has international standards so that tourists who come can feel the security and comfort when landing and take off at the airport Marinda

\section{Discussion and Result}

SWOT Analysis Method

In the SWOT method there are 2 factors: internal and external factors. According to internal factors, when Strength is more dominant than weakness it will be better under study conditions. If the weakness is bigger than the strength it will have a negative impact in the research.

In addition to internal factors, there are external factors that are; Opportunities and Threats. This external factor that is not directly affected to the research variables. The influence of these external factors must be balanced in order to produce a strategy to deal with them.

Based on the data then for the SWOT method results include strength,weakness,opportunity and threats. The research variables are: 1. Strength (S), with research indicators:

a. Stable wave heights 
b. Stable wind speed

c. Adjacent location to the sea

d. Hilly geographical condition of

e. A very popular tourist spot

f. The Mega float system supports research

g. Support from local officials and State officials

2. Weakness (W), research indicators are:

a. Waters territory in the form of coral reef conservation area

b. Wave height that can reach a height of $3 \mathrm{~m}$

c. The cost of development is very expensive

3. Opportunity $(\mathrm{O})$, research indicator is:

a. Able to increase airport capacity

b. Simplify the tourist access to Raja Ampat

c. Opening Marinda airport into International airport

d. Being an airport on the water with the first megafloat concept in eastern Indonesia.

e. Increase State revenue.

4. Threat $(\mathrm{T})$, research indicator:

a. The threat of waves

b. Commitment of local officials to maintain facilities.

c. Commitment of the community to maintain the facility.

Based on the SWOT analysis, it can be seen that the strategies that can be applied for research on the extension of runway in Raja Ampat seas are described as follows:

1. The SO strategy (Strength-Opportunity) is to use existing strengths to achieve the opportunity. To achieve these opportunities then the things that are done include:

a. Establish connections between local government and central government to accelerate project development.

b. Promoting the extension project of the airport runway to the world by making Marinda Airport becomes International to get support and promote Raja Ampat. 
2. Strategy ST (Strenght-Threat) is a strategy to maintain the position (Power) that exists in order to face the impending threat. One of them is to strengthen and build mega float structure well in order to reduce the risk of sea waves or storms.

3. WT strategy (Weakness-Threat) is to apply a system to protect or prevent against in the face of threats.

4. WO (Weakness-Opportunity) Strategy is to add facilities that can cover existing weaknesses in order to achieve or seize the opportunity. For example, patent tool needed to break the waves and also drain funds for the construction of the extension of the runway Marinda airport.

After analyzing the strategy of ST, SW, WO and WT, it is concluded that the extension of runway to marine area south of Marinda airport with Mega Float concept is a good choice because of the wave conditions, the wind speed that supports in this runway extension concept to compensate for the coming tourist data to Raja Ampat which is always increasing every year. One strategy that can be applied is the ST strategy (Strenght-Threat).

\section{Conclusion}

Considering the increased number of tourists coming to Raja Ampat which has reached to the number 17000 tourists, the development of transportation mode is surely needed. If the extension of the runway of Marinda airport remains in the length of 2000 meters by using the sea media then it will be one of the best options to see the condition of the land around the Marinda airport which is the mountains and the difficulty of land acquisition around Marinda airport ("Perpanjangan Bandara Raja Ampat Masih Dipertimbangkan,” 2017). If Raja Ampat still relies only on fast boats that take 2 hours or stay with the condition of Marinda airport that only accommodate small-bodied aircraft, then it will be difficult to develop the development of tourists who come to Raja Ampat.

Since the condition of marine waters around the airport Marinda has stable wave conditions and very profitable in the area of southern tourism, 
Waigeo Island will greatly support the extension of the airport runway to Marinda marine areas. With the concept of mega float or application like Singaraja Mafloport concept then problems like waves can be solved. Lastly, the seriousness cooperation between the local government and the central government, especially the marine minister and the minister of tourism concerning the utilization of the Raja Ampat sea area south of Waigeo Island for media runway extension will then support the development of tourism in Raja Ampat.

\section{References}

Dapat Lampu Hijau Kemenhub, Bandara Raja Ampat Siap Go International. (2017, October). Retrieved from http://www.pikiranrakyat.com/wisata/2017/10/19/dapat-lampu-hijau-kemenhub-bandararaja-ampat-siap-go-international-411824

Data Wisatawan ke Raja Ampat. (2017). Retrieved November 10, 2017, from http://www.kkpr4.net/index.php?page=page \&id=34

ICAO. (1999). ICAO Annex 14: Aerodrome Standards - Aerodrome Design and Operations, (July), 194. Retrieved from https://www.icao.int/safety/Implementation/Library/Manual Aerodrome Stds.pdf

Laadala, Z. (2017). Target Kemenhub 2017 Perpanjang Landasan Pacu Bandara Marinda. Sorong. Retrieved from http://suaraindonesianews.com/target-kemenhub-2017-perpanjang-landasan-pacu-bandaramarinda/

Martono, K., \& Marina, S. (n.d.). Domestic Air Transport Regulations in Indonesia, 3(1), 1-19.

Marty, Y. (2016). Airline Customer Retention in Indonesia 2015. International Journal of Management Sciences and Business Research, 2015(2), 41-53.

Nengah Adi Mahendra, I., Ngurah Alit Putra Wiryawan, B., Gusti Ngurah Bayu Sucitra, I., \& Parie Perdana, G. (2015). Singaraja Mefloport: Bandara Dengan Konsep Megafloat Sebagai Solusi Pemerataan Pembangunan Bali Utara, 58-63.

Perpanjangan Bandara Raja Ampat Masih Dipertimbangkan. (2017). Retrieved November 12, 2017, from https://jakartagreater.com/perpanjangan-bandara-raja-ampat-masihdipertimbangkan/

Profil KKP. (2016). Retrieved November 10, 2017, from http://www.kkpr4.net/index.php?page=page $\& i d=13$

Pura1, P. A. (2017). Proyek Pengembangan Bandara Internasional Ahmad Yani Semarang. Retrieved November 10, 2017, from https://www.ap1.co.id/id/about/airport-development-

project/detail/proyek-pengembangan-bandara-internasional-syamsudin- 
noor-banjarmasin

Rafi, S., \& Rifni, M. (n.d.). SOFT SYSTEMS METHODOLOGY PADA PENGEMBANGAN BANDAR UDARA PROVINSI SULAWESI BARAT SOFT SYSTEM METHODOLOGY-BASED ON DEVELOPMENT OF AIRPORT OF WEST SULAWESI, 4(2), 159176.

Ricardianto, P., \& Rifni, M. (n.d.). Aerodrome Safety for Manouvering Area in Soekarno-Hatta International Airport Cengkareng, 2(3).

Ricardianto, R. P., \& An, C. (2015). Menara Air Traffic Control ( Atc ) Terbaik Pada Bandar Udara. Jurnal Manajemen Bisnis Transportasi Dan Logistik, (1926), 23-43.

Sato, C., \& Inoue, K. (2003). Results of 6 Years Research Project of MegaFloat. Ocean Space Utilization Technology, 436-442.

Simarmata, J., \& Keke, Y. (2017). The Influence of Travel Agent, Infrastructure and Accommodation on Tourist Satisfaction, 28(Ictgtd 2016), 281-283.

Suzuki, H. (2005). Overview of Megafloat: Concept, design criteria, analysis, and design. Marine Structures, 18(2), 111-132. https://doi.org/10.1016/j.marstruc.2005.07.006

Yamin, J. M., \& Papua, B. (2017). BADAN METEOROLOGI KLIMATOLOGI DAN GEOFISIKA STASIUN METEOROLOGI FRANS KAISEPO - BIAK STASIUN METEOROLOGI FRANS KAISEPO - BIAK, (November), 0-2. 